\title{
A csecsemő- és kisgyermeknevelő szak gyakorlati képzése - kihívások
}

\section{Gyöngy Kinga - Serfőző MóniKA}

Eötvös Loránd Tudományegyetem

\begin{abstract}
A csecsemö- és kisgyermeknevelö szak gyakorlati képzésének kialakitásakor több szempontot érdemes mérlegelni. A gyakorlati képzésben érintettek - a hallgatók, egyetemi oktatók, bölcsődevezetök, gyakorlatvezetők, bölcsődében dolgozók, gyermekek és családjaik, valamint a társszakmák képviselői- akár egymásnak ellentétes álláspontból közelítik meg a kérdést. Cikkünkben áttekintjük azokat a szempontokat, melyeket az ELTE Tanitó-és Óvóképzö Karán a gyakorlati képzés szervezésekor figyelembe szoktunk venni. Ezeket a dilemmákat úgy térképeztük fel, hogy folyamatos visszajelzést kérünk hallgatóinktól és gyakorlatvezetöinktöl.
\end{abstract}

Kulcsszavak: csecsemö- és kisgyermeknevelö szak, gyakorlati képzés, kurzustervezés

Az ELTE Tanító- és Óvóképző Karán 2010ben indult a csecsemő- és kisgyermeknevelö alapszak. A szak létesítésével egy ezen a szinten teljesen új terület integrálódott a hazai felsőoktatásba, a szociális rendszer kapcsolódott a pedagógusképzéshez. A képzési program kidolgozásánál meghatározó szerepe volt a bölcsődei nevelésben kompetens szakemberek jelenlétének. A kar erősségei közé tartozik, hogy minden szakon kiemelt jelentőséget tulajdonítunk a gyakorlati képzésnek, nincs ez másként a csecsemőés kisgyereknevelő alapszakon sem. A gyakorlati képzés tervezését sok szempont befolyásolja, például a szakmai elvárások, a finanszírozás, a bölcsődei intézményrendszer. Figyelembe kell venni a hallgatók igényeit, az oktatók kapacitását, a bölcsődében dolgozó gyakorlatvezetők szempontjait és kiváltképp a bölcsődés gyermekek (és családjaik) szükségleteit. Néha ütköző szempontok és érdekek mentén kell kialakítani egy jól működő, eredményes rendszert, mérlegelni kell a pro-kontra érveket, egyensúlyozni kell az előnyök és hátrányok között.

A képzés kezdete óta fontos - a szak újdonsága miatt még inkább - a visszajelzés kérése az érintettektől. Ez nem csupán az oktatók közti eszmecserét jelenti, hanem a hallgatók véleményének kikérését és szakmával való párbeszédet is ${ }^{1}$.

\footnotetext{
${ }^{1}$ A visszajelzések és szakmai eszmecserék kialakításában jelentős szerepe volt Mészárosné Dr. Darvay Sarolta szakfelelősnek.
}

A hallgatóktól formális és informális módokon kérünk visszajelzést a képzés egészére, és specifikusan a gyakorlati képzésre vonatkozóan („félidős” felmérés, illetve fókuszcsoport, kérdőívek). A szakma képviselőivel való személyes találkozásra lehetőséget adnak a gyakorlatvezetői tájékoztatók, illetve fontosak a záróvizsgák, ahol a szakma képviselői is jelen vannak külső szakértőként. Példaértékű, hogy a záróvizsgák után a szakfelelős egyeztet a tapasztalatokról a záróvizsga bizottságok résztvevőivel. Ezekre alapozva a kezdetektől fogva történtek kisebb változtatások a képzési programban (Rózsáné és Aggné, 2014), tantervben.

A felhalmozódó tapasztalatok birtokában, az új képzési és kimeneti követelmények alapján megvalósuló tantervi reformhoz is kapcsolódva a csecsemő- és kisgyermeknevelő alapképzési szak hetedik évében nekiláttunk a gyakorlati képzés megújításának. Az átdolgozáskor figyelembe vettük az addig markánsabban megjelenő problémaköröket, ezek bemutatására vállalkozunk tanulmányunkban.

\section{A gyakorlat tervezése, kísérése, értékelése}

A gyakorlati képzés tartalmát a képző intézmény dolgozza ki és kommunikálja a gyakorlóhelyek, valamint a hallgatók felé. Emellett valamilyen szinten támogatja a hallgatót a 
A csecsemő- és kisgyermeknevelő szak gyakorlati képzése - kihívások

gyakorlóterepen szerzett élményeinek feldolgozásában és értelmezésében, valamint ellenőrzi, értékeli a gyakorlati teljesítményt. Ez különböző szintű oktatói bevonódással történhet.

Egyrészt kérdés, hogy a gyakorlati képzés tartalmának kidolgozásában kik vesznek részt. Optimális, ha a gyakorlóhelyek szakértőinek ${ }^{2}$ bevonásával történik a tartalom kialakítása, illetve ha nem csak a neveléstudományok képviselöi, hanem a szak egyéb (pl. gondozási, egészségtudományi, művészeti) tárgyait oktató kollégák is megvitatják a gyakorlóhelyen végzendő hallgatói feladatokat (így müködik a gyakorlati képzés az antwerpeni Karel de Grote-Hogeschool kisgyermekpedagógiai szakán Lien Werbrouck képzésvezető elmondása szerint, 2018 szóbeli közlés).

A hallgatói gyakorlat kísérése oktatói kapacitásbeli kérdéseket vet fel. Mivel a bölcsődében az óvodapedagógus szaktól eltérően nincs csoportos gyakorlat, ezért nagyszámú hallgató esetén megoldhatatlan az, hogy mindegyik hallgató gyakorlatát meglátogassa egy egyetemi tutor. Emiatt alkalmazza az ELTE TÓK a gyakorlatok kiszervezését, és bízza a hallgatókat a bölcsődékben dolgozó gyakorlatvezetőkre.

A gyakorlóterepen megvalósítandó feladatok tartalmának kidolgozásában - tapasztalataink szerint - igen fontos a gyakorlatvezetőkkel való egyeztetés. Két lehetőség adott a gyakorlatvezetői megbeszélésre, mindkettőnek megvannak az előnyei és hátrányai. Az egyik lehetőség, hogy a gyakorlatvezetőket meghívjuk az egyetemre egy csoportos tájékoztatóra. Ennek előnye, hogy a gyakorlatért felelős oktató(k) számára időtakarékos és a különböző gyakorlóterepek szempontjai a hozzászólások révén egyszerre érvényesülnek. Hátránya, hogy a csoportos megbeszélés alattesetleg nem mernek kérdezni a kevésbé

\footnotetext{
${ }^{2}$ Köszönettel tartozunk Nemes Takách Erzsébetnek, Tárnoki Erzsébetnek, Lukács Miklósnénak, Koscsóné Kolkopf Juditnak, Bucsek Zsuzsannának, Kása Imrénének, Kovács Erzsébetnek, Csepeli Gabriellának, Koncsekné Ferik Erikának és Sártory Zsófiának a visszajelzéseikért, együttgondolkodásukért.
}

tapasztalt gyakorlatvezetők. Ha a gyakorlóhelyek csak egy főt delegálnak a megbeszélésre, miközben többen fogadják a hallgatókat, akkor végeredményben nem jön létre a találkozás a gyakorlati képzési koordinátor és valamennyi gyakorlatvezető közt, az információ esetleg a többszörös továbbítás miatt elvész. Ennek kiküszöbölésére a megbeszélések öszszefoglalóját e-mailben el szoktuk küldeni a gyakorlatvezetőknek a hallgatói segédletekkel együtt. A másik lehetőség a gyakorlatvezetői megbeszélésre, hogy az egyetemi oktató felkeresi a bölcsődét, és a bölcsődében gyakorlatvezetést vállalókkal átbeszéli az adott féléves feladatokat. Ekkor jobban célba ér az üzenet, azonban az egyetemi oktató(k)nak roppant időigényes végiglátogatni az összes hallgatói gyakorlóhelyet (az ELTE-n csak a nappali tagozaton évfolyamonként 50-60 hallgatóval kell számolnunk). Új gyakorlóhelyek toborzásakor érdemes ezt a formát választani.

A gyakorlat kísérésének másik módja az egyetemen szervezett csoportos gyakorlatkísérő szeminárium. Az ELTE csecsemő- és kisgyermeknevelő szakán az utolsó féléves egyéni összefüggő terepgyakorlathoz tartozik esetmegbeszélő kísérőszeminárium, mely lehetőséget ad a kollegiális esetmegbeszélésre (Tietze, 2016), illetve a csoportos szupervízióra. A képzés első öt félévében a gyakorlatok kísérésére nincs kijelölt szeminárium, bár egy-egy kurzuson célzottabban lehetőség lenne rá, ha az oktatók szorosabban együttmüködnének a gyakorlati képzéssel. Például jó tapasztalataink vannak arról, hogy a negyedik féléves pedagógiai pszichológia szemináriumon az órai témához kapcsolódva a gyakorlati tapasztalatokat beszéljük meg. Az oktatás is életszerűbbé válik, és lehetővé válik a hallgatók gyakorlati tapasztalatainak elméleti keretben való értelmezése is.

Egy-egy félévben a gyakorlat több tevékenységből áll, így a gyakorlati teljesítmény értékelése is több hallgatói feladatból tevődik össze. A képzés kezdetén Rózsáné Czigány Enikő honosította meg a portfólió típusú számonkérést. Ennek előnye az volt, hogy a hallgatók a gyakorlatok során szerzett információkat elemezve, reflektáltan foglalták ösz- 
sze. Azonban, mivel egy portfólió több rövid írásból tevődöttössze, végeredményben hallgatónként átlagosan 15-20 oldalas lett, mely az értékelést végzőknek igen megterhelő volt. A Canvas elektronikus tanulásmenedzsment keretrendszerre való átállás egybe esett a gyakorlati képzés tartalmi megúiításával. Lehetőség nyílt például a megtanulandó tudástartalmak kvíz típusú automatizált lekérdezésére, így az oktatóknak már csak a félév végi reflektív esszéket kell elolvasniuk és értékelniük.

A gyakorlati tevékenység értékelésében nagyobb szerepet adtunk a bölcsődei gyakorlatvezetőknek a korábbi évekhez képest. Egyrészt megkértük őket, hogy a megfigyelések alapján készülő írásbeli feladatok értékelésében vegyenek részt, hiszen ezek hitelességét csak a terepen jelen levők tudják megítélni. Másrészt a gyakorlatvezetők kérésére lehetőséget teremtettünk a hallgatók gyakorlati teljesítményének értékelésére. A hallgatói gyakorlati feladatvégzés szintjét a gyakorlatvezetők különböző szempontok mentén, hétfokú skálákon értékelik, az írásbeli feladatoktól függetlenül. Az adott félévi nevelési gyakorlat összértékelése a félév során szerzett különböző értékelésekből tevődik össze.

\section{Egyetemi kontaktóra hiánya a gyakorlati képzés támogatása során}

A gyakorlati képzés támogatásához nem tartozik egyetemi kontaktóra ${ }^{3}$, pedig számos információt át kell adnunk a hallgatóknak. Ezeket a félévek elején tartott tájékoztatók során szoktuk elmondani, illetve a hallgatók (nappali és levelező tagozaton együtt legkevesebb 120 fó) az egész félév során feltehetik kérdéseiket e-mailben a gyakorlati képzés koordinátorának.

A hallgatók tájékoztatásában nagy előrelépést jelentett a Canvas e-learning keret-

\footnotetext{
3 A felsőoktatási szakmai gyakorlatokkal kapcsolatban a 2011. évi CCIV. törvény a nemzeti felsőoktatásról így fogalmaz a 108. \$-ban: a szakmai gyakorlat „felsőoktatási szakképzésben, alap-, mester- és osztatlan képzésben, külső gyakorlóhelyen vagy felsőoktatási intézményi gyakorlóhelyen teljesítendő részben önálló hallgatói tevékenység".
}

rendszerre való átállás. Ebben a hallgatóknak a leveleken kívül hang- és videóüzenetet is tudunk küldeni, táblázatban össze tudjuk foglalni a teendőiket. Lehetővé vált oktatófilmek megosztása is, könnyebbé vált a hallgatói dolgozatok beadása és értékelése, és a határidők kezelése.

Hasonlóan az amerikai katonaság kisgyermeknevelőinek képzésére szolgáló Virtual Lab School ${ }^{4}$ tapasztalataihoz (Buettner, Lang E Jeon, 2018), mi is átéltük, hogy a képzés online áttételével nem várt pozitívumok jártak. Ugyanis a hallgatói feladatokon túl a segédleteket is igen részletesen kidolgoztuk, példamegoldásokkal láttuk el. Értékelőtáblát készítettünk a feladatokhoz, mellyel átláthatóbbá váltak az értékelés szempontjai mind a diákok, mind az oktatók és az értékelésbe bevont gyakorlatvezetők számára.

Elvárás a gyakorlati képzésben, hogy a hallgatók reflektív módon gondolkodjanak (Szivák, 2014) pedagógiai munkájukról. A gyakorlatot támogató egyetemi kontaktóra hiánya ennek megvalósításában is megmutatkozott: felkészítés nélkül meglehetősen alacsony szintű írásbeli reflexiókat kaptunk. Ennek orvoslására két megoldás kínálkozik. Egyrészt megkereshetjük az elméleti képzés oktatóit, és megbeszélhetjük velük, ki, melyik kurzus keretében készíti fel őket erre a feladatra. A másik lehetőség, hogy a gyakorlati képzésen belül távoktatás formájában készítjük fel a hallgatókat a reflektív esszé írására. A biztonság kedvéért az átdolgozáskor a másodikat választottuk.

\section{Az elméleti és gyakorlati képzés tartalmi összehangolása}

Az előzőekből is látható volt, hogy a gyakorlati képzés akkor lesz jól müködő, ha szervesen kapcsolódik az elméleti órákhoz, lehetőséget

\footnotetext{
${ }^{4}$ A Virtual Lab Schoolt (Virtuális Labor Iskola) az amerikai Védelmi Minisztérium felkérésére az Ohio Állami Egyetemi munkatársai dolgozták ki és fejlesztették (dr. Cynthia Buettner vezetésével) az amerikai a Nemzeti Élelmezési és Mezőgazdasági Intézet támogatásával. Ingyenesen elérhetők tananyagjai az interneten.
} 
A csecsemő- és kisgyermeknevelő szak gyakorlati képzése - kihívások

ad arra, hogy a hallgató az újonnan szerzett ismereteit kipróbálhassa. Ez azonban a szak oktatói között egyeztetést kíván a tanított tartalmak és módszerek tekintetében. Szükséges, hogy az egyetemi oktatók tisztában legyenek azzal, milyen szakmai feladatra kell felkészíteniük a hallgatókat. Például, az első félévben tartott Fejlődés és játék szemináriumon videófelvételeken gyakoroljuk a megfigyelést, majd ezt a készségüket a gyakorlati képzésben használniuk is kell.

Azért is jó az elméleti tárgyakat összehangolni a gyakorlattal, mert így elkerülhető, hogy egy feladatot kétszer végeztessünk el a hallgatókkal (és a hallgató ugyanazt a munkát két helyre adja le). Valamint, ha az oktatók ismerik a gyakorlati képzésben kiadott feladatok sokszínűségét, és beleszólhatnak a feladatok kialakításába, nem érzik szükségét annak, hogy a gyakorlati időt plusz megfigyelési feladatokkal terheljék.

A gyakorlati képzésben a félévenkénti feladatokat úgy válogattuk össze az átdolgozáskor, hogy nem csak azt vettük figyelembe, hogy a hallgatók milyen elméleti tudást kaptak már meg az egyéb óráikon, hanem a féléveket tematizáltuk. Így az első félév a napközbeni ellátás rendszerével való ismerkedésről szól, a második félévben a gondozással és játékkal kapcsolatos megfigyelések kaptak helyet. A harmadik félév a bölcsődei és óvodai beszoktatásról-befogadásról szól, a negyedik félév a gyermekvédelemről. Az ötödik félévben foglalkoznak hallgatóink a sajátos nevelési igényű gyermekek bölcsődei integrációjával, hatodik félévben pedig egyéni összefüggő terepgyakorlatukat töltik.

Továbbá, számba vettük a pedagógusminősítéshez szükséges kisgyermeknevelői portfólió (Bata és mtsai, 2016) elemeit, és ezeket - némi adaptációval - beemeltük a gyakorlati képzés írásbeli feladatai közé.

Az elméleti és gyakorlati képzés összehangolása folyamatos egyeztetést, eszmecserét kíván, időigényes feladat. A képzés fejlesztésére - a felsőoktatás általánosan jellemző működésmódjai miatt - nehéz elegendő időt és terepet kínálni még akkor is, ha megvan az együttműködési szándék.

\section{A megfigyelés és aktív tevékenység aránya}

A gyakorlati képzéssel kapcsolatos visszajelzésekben szinte mindig felmerült, hogy kevés a bölcsődében töltött gyakorlat, sok a megfigyelés, a hallgatók eleinte nem nyúlhatnak a gyerekekhez, mert a gyermekek érdeke mást kíván. Ahhoz, hogy ezt a dilemmát megértsük, érdemes az előzményeket megvizsgálnunk.

\section{Bölcsödei hagyomány}

Magyarországon az 1950-es években nagy számban jöttek létre bölcsődék, ahol csecsemők megőrzése is zajlott. A körülmények nem voltak kielégítők. „A bölcsődékben gondozott gyermekek minden erőfeszítés ellenére sem fejlődtek a vártnak megfelelően, a hospitalizáció súlyos vagy kevésbé súlyos tüneteit lehetett náluk megállapítani" (Vokony, 2002. 53. o.).

Pikler Emminek, a Lóczy úti csecsemőotthon vezetőjének célja volt, hogy kidolgozza az intézményes nevelésnek azt a módját, melyben nem áll fenn a csecsemők és kisgyermekek hospitalizálódásának veszélye. 1966-ban az Orvosi Hetilapban jelent meg cikke (Péterné Pikler, 1966a), mely a kisgyermeknevelési intézményekben zajló oktatási gyakorlatok kockázatait taglalja.

Pikler (1966a) rávilágított arra, hogy a csecsemőnek természetes igénye a személyes kapcsolat kialakítása az őt gondozó felnőttel. Ha sikerül a kapcsolat kialakítása, az azzal jár, hogy az idegenek iránt a csecsemő tartózkodóvá válik. Az idegen ez esetben a gyakorlatot végző hallgató. Azaz a jól fejlődő csecsemő természetes módon nem kooperál az őt gondozni próbáló ismeretlennel. Nagy bajra utal, ha egy csecsemő azért könnyen kezelhető, mert hidegen hagyja, ki gondozza őt, főképp, ha „viaszbabaként” hagyja, hogy hozzányúljanak. (A hospitalizálódott csecsemő indifferens az őt gondozó személyekkel kapcsolatban.) Ha egy hallgató hospitalizálódott „kisgyermekeken gyakorol", helytelen kép alakulhat ki benne azzal kapcsolatban, mi az elvárható viselkedés egy csecsemőtől vagy kisgyermektől. 
Ennek kivédésére azt a javaslatot tette Pikler 1966-ban, hogy egy csoportban egyszerre csak egy hallgató gyakoroljon, méghozzá úgy, hogy az adott hallgató képzési ideje alatt ugyanabba a csoportba tér vissza, és egy csoport egy képzési időszak alatt csak egyetlen egy hallgatót fogadjon.

E felvetésre Farkas Márta csecsemőotthon igazgató válaszolt (Farkas, 1966). Válaszában kétségbe vonta Pikler Emmi borúlátását a gyakorlatok súlyos következményei tekintetében, noha elismerte, hogy az „új személy megjelenése és gyakorlatlanságából adódó problémák rendszerint a gyakorlat elején (3-4 napig) egy bizonyos fokú nyugtalanságot idéznek elő, utána gyorsan normalizálódik a helyzet" (Farkas, 1966. 1387. o.). Ugyanakkor azt is írta, hogy „a jelenlegi létszámviszonyok mellett csecsemőotthonainkban a tanulónővérek munkája révén több idő jut egy-egy gyermekkel való foglalkozásra, és ez a körülmény előnyösen járul fejlődésük meggyorsításához" (Farkas, 1966. 1387. o.).

Pikler Emmi viszontválaszában (Péterné Pikler, 1966b) a kettejük közti szemléletbeli különbségről szólt, mondván, a rövid távú ismétlődő nyugtalanító hatásokat is érdemes kiiktatni a csecsemőotthonban élő gyermekek életéből, illetve, hogy vétségre utal, ha a tanulónővérek munkája révén több idő jut egy-egy gyermekkel való foglalkozásra, mivel ez csak akkor valósulhat meg, ha a tanulót nem felügyeli az épp ellátott gyermek sajátgondozónője.

A vita (az írott publikációk szintjén) két évtized múlva folytatódott. Ekkor Stróbl Mária cikke volt a kiindulópont, mely az Egészségügyi Munka című folyóiratban jelent meg (Stróbl, A bölcsőde mint gyakorló terület, 1984), és arról számolt be, hogy a pikleri szemléletet alapul véve, a szakgondozónőképzésben a tanulók a bölcsődében csak megfigyelési feladatokat kapnak, a gyermekekkel közvetlen kapcsolatba nem kerülhetnek. Erre a cikkre több válasz is érkezett.

Csatári Irén, a Csecsemőotthonok Országos Módszertani Intézetének szakoktatója a főiskolás védőnő hallgatók csecsemőotthoni gyakorlatának tapasztalatairól írt (Csatári, 1985), mintegy megerősítve Stróbl álláspontját. Csatári cikke szerint a Bölcsődék Országos Módszertani Intézetében kidolgozott szempontok alapján a föiskolások kéthetes csecsemőotthoni gyakorlatuk során csak megfigyeléseket végezhettek. Ezeket a megfigyeléseket gondosan elökészítették filmek és fotók elemzésével. Ezután következett a csoportos megfigyelés, melynek során a hallgatók leírták a látottakat. A két hét során először a gondozónő és a gyermek interakcióját figyelték meg, majd a fürdetést és az etetést, végül a gyermekek manipulációját és játékát. A megfigyeléseket a szakoktatók a hallgatókkal csoportosan megbeszélték, majd elemezték. Végül a hallgatók írásban adták le a megfigyeléseiket, egyéni elemzéssel kiegészítve. Csatári tapasztalatai szerint az attitűd formálásában volt szerepe ennek a megfigyelési gyakorlatnak, megtanított látni, rácsodálkozni a kisgyermeknevelés részleteire.

Stróbl (1984) és Csatári (1985) álláspontjának kihívója Szél Éva (1985) volt, a szegedi védőnőképző szak oktatója. Szél kétségbe vonta, hogy a szakmai gyakorlat kimerülhet kizárólag megfigyelések végzésében, főleg, hogy a tanterv a gondozási müveletek begyakorlását is előírta. Szél cikkében (1985) feltette azt a kérdést is, egyértelmű tényként fogadhatjuk-e el, hogy a hallgatói gyakorlatok a gyermekek károsodásához vezetnek, kiváltképp, ha a sajátgondozónő jelenlétében zajlanak. Ezzel együtt kétségbe vonta, hogy Pikler 1966-os feltételezése - mely szerint a hallgatói gyakorlatok hozzájárulnak az intézményekben nevelkedő csecsemők hospitalizálódásához - két évtizeddel később a bölcsődékre is érvényesek volnának ${ }^{5}$. Szél (1985) gondolatmenetét folytatva feltette azt a kérdést is, nem vét-e a képzés azáltal, ha kizárja a hallgatókat a gyermekekkel való kapcsolatfelvételből, és így nem is győződik meg arról, képesek lennének-e egyáltalán a gyermekekkel való kapcsolatteremtésre.

\footnotetext{
5 „A csecsemőotthonok gyermekeit lehet-e kiindulási alapul venni biztos családi háttérrel és családi kötődéssel rendelkező bölcsődés gyermekek megítélésénél?" (Szél, 1985. 76. o.).
} 
A csecsemő- és kisgyermeknevelő szak gyakorlati képzése - kihívások

Szél Éva cikkére a válasz ismét két helyről érkezett, a CSOMI és a BOMI oldaláról egyaránt. A Csecsemőotthonok Országos Módszertani Intézete nevében Falk Judit (1985) válaszolt, míg a Bölcsődék Országos Módszertani Intézete álláspontját ismét Stróbl Mária (1985) tolmácsolta.

Falk (1985) cikkének bevezetőjében arról írt, hogyan alakult ki az együttműködés az 1975-ben alakult Egészségügyi Főiskolai Kar és a CSOMI, BOMI közt a védőnőhallgatók nyári gyakorlatának biztosítására, valamint leszögezi, hogy „a megfigyelési szempontok érdemi felhasználása [...] mind a hallgatók, mind a gyakorlatvezető részéről elmélyült, olykor a manuális gyakorlatnál igénybevevőbb munkát" (Falk, 1985. 274. o.) jelent. Ezt követően három szempontot vetett fel a megfigyeléses gyakorlatok védelmében.

Falk (1985) elsőként a gyermekek szempontját említette. Több külföldi tanulmányra hivatkozott, melyek szerint az intézményben nevelkedő csecsemők fejlödésére a hallgatói gyakorlatok kedvezőtlenül hatnak, mivel roszszabb esetben megakaszthatják a csecsemők testi gyarapodását (Bertoye E Dumorand, 1957), de mindenképp interferálnak a sajátgondozónő és a csecsemő közti kapcsolattal (Rheingold, 1956). Ha azonban kiküszöbölhető a gondozásban részt vevő személyek cserélődése, az „mind a gyerek, mind a felnőtt számára lehetővé teszi egymás jelzéseinek, gesztusainak, viselkedésének kölcsönös megértését s az egyre árnyaltabb, individualizáltabb bánásmód forrásává válik" (Falk, 1985. 275. o.) Falk egy külföldi bölcsődei álláspontra is hivatkozott (bár nem titkolta, hogy ezt az álláspontot épp a „magyarországi Lóczy modell tanulságát felhasználva" (Falk, 1985. 275. o.) alakította ki (Davidson és Maguin, 1976). A gondozónői stabilitás értelmében e szerint „bölcsődék növendékeket csak hosszú időre és csak magas heti óraszámban fogadhatnak gyakorlatra. Több növendék párhuzamos vagy váltott műszakban történő gyakorlatát azonos gyermekcsoportban és a néhánynapos „villámgyakorlatokat” szerintük határozottan meg kell tiltani" (Falk, 1985. 275. o.). A gyermekek szempontjából Falk (1985) másik érve az volt, hogy a hallgató csak rövid ideig van jelen a gyermek életében, kapcsolatuk jövő nélküli, éppen ezért a gyermek testét érintő legintimebb kapcsolatba, a gondozásba nem kellene bekapcsolódnia.

Falk (1985) másodikként az oktatásban részt vevő hallgatók szempontját tárgyalta. Említette a pikleri érvelést, mely szerint egy egészséges fejlődésű kisgyermek nem kooperál az idegennel. A jó gondozás alapja a kisgyermek igényeinek ismerete, az ezekhez való alkalmazkodás, azonban a hallgatóknak nincs ideje a gyermekeket megismerni. Ezen túl rávilágított, hogy a védőnőhallgatóknak leginkább az újszülöttekkel való bánásmódot kellene elsajátítania, amire a csecsemőotthonokban is kevés lehetőség nyílik, a bölcsődékben pedig semmi.

Harmadik szempontként Falk (1985) az intézményi gyakorlat hallgatói szemléletre gyakorolt hatását tárgyalta. Az oktatás fontos célja, hogy a hallgatóknak átadja azt a meggyőződést, hogy „a gondozás nem egyszerüen technikai müvelet, hogy a csecsemő nemcsak türi a gondozási műveleteket, hanem aktív résztvevőjük is lehet legkisebb korától kezdve, hiszen a gondozás a szociális tapasztalatainak legfőbb forrása, korai kompetens viselkedésének legfőbb területe" (Falk, 1985. 277-278. o.).

Falk (1985) a gyakorlat szervezésével kapcsolatban több javaslatot is tett. Szerinte a gondozás technikájának elsajátítására megfelel a kiscsoportos tantermi gyakorlat során a demonstrációs baba. Az így szerzett készséget élő gyermekeken csak akkor fejlesztheti tovább a hallgató, ha már munkát vállal és egy csoportnyi gyermek hosszú távú ellátására szerződik. A korabeli képzési rendszer lehetővé is tette ezt, hiszen a középfokú szakközépiskolai végzettség után 10 hónapos munka melletti szakosító képzésben vettek részt a gondozónővé válni kívánó hallgatók. Védőnőhallgatóknak a csecsemőotthoni és bölcsődei gyakorlat helyett kórházi újszülöttosztályos illetve csecsemőosztályos gyakorlatot javasolt, vagy a képzés megkezdésének feltételeként egyéves bölcsődei vagy csecsemőotthoni munkaviszonyt. 
E javaslatokkal kapcsolatban érdekesség, hogy a képzettség nélkül való elhelyezkedésben nem láttak problémát. Mint egy másik tanulmányból (Stróbl, 1985) kiderül, ez úgy valósult meg, hogy a kezdő gondozónő néhány hónapig kisegítőként dolgozott a gyermekcsoportban, majd fokozatosan kezdte meg az egyik alcsoport gyermekeinek ellátását. Összességében ez a kezdő gondozónőtől a napjainkban megszokottnál jóval kevesebb munkavállalói önállóságot várt el, miközben a betanítás terhét az intézményre rótta. Falk (1985) tanulmánya abból a szempontból is tanulságos, hogy a védőnő hallgatók esetében felveti, valóban szükséges-e, illetve milyen formában tanulságos a hallgatóknak az intézményes gyakorlat. Amennyiben az újszülöttek gondozásának technikáját kell begyakorolniuk, akkor erre olyan gyakorlóterepet kell találni, ahol újszülöttek vannak.

A vita zárásaként Stróbl hozzászólása jelent meg az Egészségügyi Munka c. folyóiratban (Stróbl, 1985). Stróbl tanulmányában külön tárgyalta a középfokú gondozónőképzés és a felsőfokú védőnőképzés gyakorlati képzésének kérdéseit. A középfokú gondozónőképzés gyakorlati képzésének nehézségei közt említette az alábbiakat, melyek oda vezettek, hogy a BOMI a megfigyeléses gyakorlatok mellett tette le a voksát:

- a gyakorlóbölcsődékben az egyidejü nagyszámú hallgatói jelenlét

- az órarendbe oly módon illesztett bölcsődei gyakorlati óra, melyet más helyszínen elméleti óra előz meg és követ (a hallgatók bölcsődében töltött ideje emiatt minimális)

- a tantervben levő következetlenségek a gyakorlati feladatok és az elméleti tudás oktatásának ütemezésében (a gyakorlati feladat megelőzi az elméleti tudás elsajátítását)

- a gyermekekre gyakorolt negatív hatások: „[1979-ben a] 3 hetes szakiskolai gyakorlat végén gondozónőink kétségbeesve kérték, hogy többé ne engedjük a tanulókat a gyerekek közé, mert egész évi következetes gondozónevelő munkájuk és a gyermekek jó közérzete látta kárát a gyakorlatnak. Ilyen jellegű panaszt több bölcsődéből jeleztek. Kiszállásaink alatt láttuk, ahol a szakoktatók fokozottabb kérlelésének eleget téve besegíthettek a tanulók a gondozási munkákba, nagy igyekezetük miatt szinte visszaminősítették a gyermekeket az önálló evésben, kézmosásban, öltözködésben. A gyermekek tiltakoztak, egyik-másik a szülők elmondása szerint nem szívesen ment reggel a bölcsődébe" (Stróbl, 1985. 282. o.).

A Stróbl által említett problémák közül az első három aránylag könnyen orvosolható. Az utolsó pont azonban elgondolkodtató. Noha ezelőtt négy évtizeddel szerzett tapasztalatokról van szó, a hallgatói gyakorlatok gyermekekre gyakorolt negatív hatásainak minimalizálása a gyakorlatok kialakításának elsődleges szempontja kell, hogy legyen.

Mindamellett tagadhatatlan, hogy a mai gyermekek élete „kitágult” a rendszerváltás előtti időkhöz képest, több inger veszi körül a mai csecsemőket. A gyermekeket körülvevő társas közeg is megváltozott, rövidebb távú (piaci alapú) kapcsolatok is megjelentek, például a családok életében ma már bébiszitter(ek) is jelen van(nak), akik ismeretlenül kapcsolódnak be rövidebb-hosszabb időre a gyermek gondozásába-nevelésébe, és sok esetben szakképzettségük sincs.

A rendszerváltozás utáni átalakulás nem csak a családokat érte el, hanem a szakképzést is. Az 1990-es évek elején a szakképzés átalakítása világbanki hitellel valósult meg (Nyitrai, 2016). A „világbankos képzésbe” a szakmai elvárások szerint visszakerült a gondozónő jelöltek gyermekekkel való aktív tevékenysége. Azóta is jelen van a gyermekekkel való aktív tevékenység a képzésekben, akár középfokú, akár felsőfokú képzésről beszélünk. A múltbéli - gyermekek védelméről szóló - szempontokat tehát úgy kell napjainkban érvényesítenünk, hogy a hallgatók nem zárhatók ki a gyermekekkel való foglalkozásból.

A gyermekek igényeinek figyelembevétele a gyakorlat szervezésekor

A pedagógusképzésben hagyományosan gyerekeken gyakorolja készségeit a pedagógusjelölt. A három éven aluli korosztály életkori sajátosságai azonban különös óvatossá- 
A csecsemő- és kisgyermeknevelő szak gyakorlati képzése - kihívások

got tesznek szükségessé, amikor a gyakorlatot tervezzük, mint ahogy ezt a fent bemutatott vita is érzékeltette. Mindezek fényében az ELTE Tanító- és Óvóképző Karán a kisgyermeknevelő alapszak gyakorlatai során az alábbi elveket alkalmazzuk:

- Gyakorlatvezetőinket kérjük, hogy egy csoportba csak egy hallgatót engedjenek.

- Hallgatóinkat ugyanabba a bölcsődébe, ugyanahhoz a gyakorlatvezetőhöz irányítjuk gyakorlatra a képzés első öt félévében.

- Egy gyakorlati helyre csak minden második évben küldünk hallgatót, azaz egyszerre egy bölcsődében csak elsőés harmadéves nappalis hallgató(k) lehet(nek). Ez azért megengedhető, mert első félévben csak két napot töltenek a hallgatók a bölcsődében a rendszerrel való ismerkedés jegyében, amikor a harmadéveseinknek ötödik félévben már aktív feladata van. Amikor pedig a második félévben az elsőévesek gyermekekkel kapcsolatos gyakorlati feladatai elindulnak, addigra a harmadévesek sokszor elhagyják az intézményt, ugyanis a hatodik félévben az összefüggő gyakorlatra a hallgatók sokszor más helyszínt választanak jövőbeni elhelyezkedési terveiknek megfelelően. Így egyszerre megoldható a gyakorlóhelyek optimális kihasználása és a gyermekek védelme.

- Az utolsó félévben, amikor a hallgató egyéni összefüggő gyakorlatát tölti, javasoljuk neki, hogy azt az intézményt válassza gyakorlóhelynek, ahol később el szeretne helyezkedni.

- A hallgatói gyakorlatokat tipikusan két év feletti gyermekcsoportba szervezzük. Csecsemőt csak megfigyel a hallgató, nem kerül vele közvetlen kapcsolatba.

- Az első három félévben a megfigyelési feladatok dominálnak a gyakorlati képzésben. Ahogy a nevelés-gondozás irányába tolódnak a hallgatói feladatok, a gyakorlat szervezésének módja is megváltozik: a heti egy napos gyakorlatok helyett ettől kezdve összefüggő napokat, heteket tölt a hallgató a bölcsődében, ezalatt az egyetemi óráiról igazoltan hiányzik.
- Az intenzív gyakorlatokat megelőző elméleti órákon hangsúlyozzuk a korai kötődés jelentőségét, a korai életévek sajátosságait.

- A bölcsődei gyakorlatok során több olyan feladatot kapnak a hallgatók, mely a gyermekek kapcsolatairól, illetve a gyermeki nézőpontról szólnak, például első félévben a hallgatók interjút készítenek egy bölcsődés gyermek szüleivel a bölcsődébe adás okairól, körülményeiről. Ugyancsak az első félévben megfigyelik egy kisgyermek egész napját a bölcsődében. Harmadik félévben kívülálló megfigyelőként követik végig egy kisgyermek bölcsődei beszoktatásának egy hetét. Ezeknek a feladatoknak a célja, hogy a hallgatók megtanulják értékelni a gyermek kapcsolódási igényét és azokat a kapcsolatokat, melyekre hosszú távon számíthat.

Felhívjuk a hallgatók figyelmét, hogy a gyermekekkel lassan, tapintatosan ismerkedjenek.

- Amikor a hallgató oda jut a feladataiban, hogy a gondozásba is bekapcsolódhat, olyan kisgyermek gondozását végzi, aki elfogadja őt és azt, hogy kisgyermeknevelője helyett gondozza.

- Gyakorlatvezetőinknek javasoljuk, hogy végezzék el a csecsemő- és kisgyermeknevelés gyakorlatvezető mentora c. szakirányú továbbképzésünket, mely felkészíti őket a hallgatók támogatásával kapcsolatos pedagógiai feladatokra.

Bizakodásra ad okot, hogy egy gyakorlatvezetői felmérésünk szerint a válaszadók 60\%-a nem értett egyet azzal az állítással, hogy a gyakorlati feladatok megzavarták a bölcsőde mindennapjait (l. ábra). 


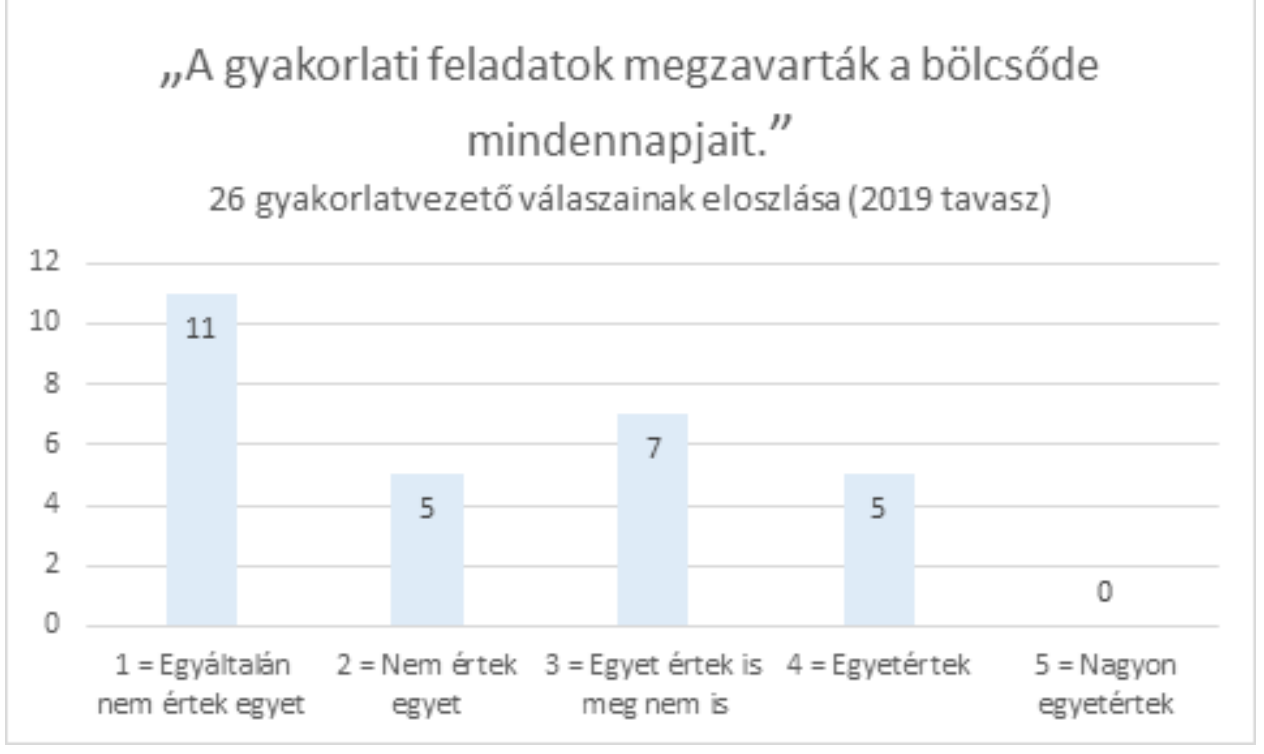

1. ábra: Gyakorlatvezetői vélemények megoszlása

\section{Bölcsődei gyakorlati idő hossza, szervezésének módja}

A gyakorlatok szervezése nem elhanyagolható a bölcsődében töltött idő hasznosíthatóságában. Egyrészt, ha adott óraszám áll rendelkezésünkre a hallgatói gyakorlatokra, akkor érdemes ezeket teljes mértékben bölcsődében, csoportban töltendő időre használni, és a hallgatók írásbeli feladatait nem a tantervi órák terhelésébe beszámítani. Továbbá, jobban hasznosul a gyakorlat, ha a hallgatók egy teljes hetet töltenek összefüggően a bölcsődében, mint ha öt héten keresztül egy-egy napot szánnánk a gyakorlatra. A tömbösített gyakorlat esetében sajnos elvész annak a lehetősége, hogy a hallgató egy félév során a gyermekek fejlődését végigkövesse, de könnyebb bekapcsolódnia a csoport életébe, és egy hét történéseit folyamatában láthatja.

A féléves gyakorlatok során kiaknázzuk a különböző szervezési módokban rejlő előnyöket. A második félévben, amikor a hallgatóknak sok megfigyelési feladatuk van, egy héten egyszer vannak bölcsődében, a köztes napokon meg tudják írni jegyzőkönyveiket. A harmadik félévben a félév elején egy gyermek beszoktatásának egy hetét figyelik meg a hallgatók (a kisgyermekkel egy időben vannak a bölcsődében, látnak olyan napokat is, amikor a szülő jelen van a gyermekével a csoportban, majd olyat is, amikor a szülö kimegy a csoportból), majd a félév végén eltöltenek ugyanabban a csoportban ismét egy-egy napot, hogy lássák, hogyan sikerült a gyermeknek adaptálódni a bölcsődéhez. A negyedik félévtől tömbösített gyakorlatokat szervezünk a bölcsődében.

A hatodik féléves egyéni összefüggő terepgyakorlat esetében az egyetemi képzési napot - a gyakorlatvezetők kérésére - hétfőről áttettük péntekre, így hallgatóink megtapasztalhatták azt is, hogyan kezdik a gyermekek a hetet a bölcsődében.

Mindezeket a pozitívumokat anélkül sikerült elérnünk, hogy a mintatantervben meghatározott óraszámokat megváltoztattuk volna, pusztán a gyakorlatok időbeosztását észszerüsítettük.

\section{Ki a gyakorlatvezető a bölcsődében?}

Míg más pedagógusképzési szakokon a szakmai gyakorlat mentora a csoportban dolgozó pedagógus, a bölcsődében gyakran kettős mentorálás mellett fogadják a hallgatót. Ez úgy valósul meg, hogy a hallgató tájékoztatását, szakmai jellegü megfigyelését, írásbeli munkáinak és gyakorlati tevékenységének értékelését a (felsőfokú szinten képzett) intézményvezető vagy a szaktanácsadó végzi, a csoportban pedig egy (középfokú képesítéssel rendelkező) kisgyermeknevelő mutatja meg a gyakorlati fogásokat és felügyeli a hallgató munkáját. A kettős gyakorlatvezetés - bár pozitívumokat is rejt magában - kérdéseket is felvet. Kérdés, kivel ál- 
A csecsemő- és kisgyermeknevelő szak gyakorlati képzése - kihívások

lunk szerződésben, ki vállalja a felelősséget, kinek van kellő mélységü benyomása a hallgatóról a gyakorlatvégzés közben. Hosszú távon, a BAszintű képesítés elterjedésével megvalósulhat, hogy minden hallgatót felsőfokú végzettséggel bíró kisgyermeknevelő önállóan mentoráljon.

\section{Bölcsőde mellett egyéb kisgyermekekkel foglalkozó intézmények megismerése}

A csecsemő- és kisgyermeknevelő szak gyakorlati képzésének erénye, hogy a hallgatókat a bölcsődén kívül olyan egyéb intézményekkel, szolgáltatásokkal is megismerteti, melyek a három éven aluli gyermekek és családok életében fontos szerepet játszanak, és amelyekkel egy kisgyermeknevelő kapcsolatba kerülhet. Mindazonáltal az intézménylátogatások megszervezése a hallgatók nagy száma miatt problémás. Egyrészt sokszor személyes kapcsolatokon múlik, hogy egy intézmény beengedi-e hallgatóinkat, másrészt az a kérdés, tényleg fontos-e, hogy a hallgató fizikai valójában meglátogasson egy intézményt, vagy jelenléte több kárt okoz, mint hasznot pl. a perinatális intenzív centrum esetében. Ez esetben a látogatás kiváltható egy-két jól leforgatott riporttal, dokumentumfilmmel.Fontos, hogy a gyermekekre, fejlődésükre, érzelmi biztonságukra ne legyen káros hatással a hallgatói gyakorlat.

Végeredményben az egyéb ellátásokról kétféleképp jutnak a hallgatók információhoz: ahol megoldható, ott egyéni vagy kiscsoportos intézménylátogatással, más esetben pedig felajánljuk a hallgatóknak, hogy az egyetemre meghívjuk azt a személyt, aki az intézményt bemutatja. Az előadót megkérjük, hogy hozzon magával filmet intézményéről vagy az adott szolgáltatásról, illetve a Canvas tudásmenedzsment oldalon megosztunk a hallgatókkal ajánlott dokumentumfilmeket.

\section{Levelező és nappali tagozatos hallgatók igényei}

A nappali és levelező tagozatos hallgatóink érdekei esetenként egymásnak ellentmon- dóak. Míg a nappali tagozatos diákjaink arra panaszkodnak, hogy kevésnek találják a gyakorlatot, a munka mellett tanuló levelezős diákjaink sokallják, hiszen munkahelyükről szabadságot kell kivenniük, hogy a hét közben teljesíteni tudják a szakmai gyakorlatukat.

Az egyéb ellátási formákról, intézményekről szóló ismertetéseket (pl. egészségügyi alapellátás, Biztos Kezdet Ház) a hallgatói igényeknek megfelelően szombati képzési napokra tesszük. Ezeket az előadásokat az előző félév végén kell megszervezni, hogy a hallgatók órarendjébe bekerülhessen, előre tervezni tudják időbeosztásukat.

\section{Kisgyermeknevelőként dolgozó hallgatók gyakorlati feladatai, fejlődési lehetőségei}

A levelező képzésnek nagy dilemmája volt az első években, hogy a legtapasztaltabb és legfelkészültebb kisgyermeknevelők - azóta gyakorlatvezetők - voltak a hallgatók. Azóta is nagy számban gyakorló kisgyermeknevelők járnak a levelező tagozatra. Velük kapcsolatban merül fel, hogy milyen fejlődési lehetőséget kínálunk számukra a gyakorlati képzés során. A 2018-as átdolgozás során a középfokú végzettséggel dolgozó kisgyermeknevelők számára külön definiáltuk a feladatvégzés mikéntjét. Kettős célt tüztünk ki számukra: egyrészt szeretnénk, ha a megfigyelések révén a saját csoportjukba járó gyermekeket jobban megismernék és megértenék, valamint saját mindennapos gyakorlatukról beszélgetnének mentorukkal. Másrészt, fontosnak látjuk, hogy minél inkább képessé váljanak az írásbeli szakmai kommunikációra, illetve gyakorolják a pedagógusportfólió dokumentumainak elkészítését, a reflektív gondolkodást.

A dolgozó kisgyermeknevelők egyéni összefüggő gyakorlata számára is a nappalis hallgatókétól különböző célokat kell kitűznünk. Egy saját gyakorlattól különböző gyakorlat megismerése a cél, hogy a különbözőségek és hasonlóságok révén elgondolkozzanak a szakma lényeges részein. Ennek kapcsán felmerül egy olyan szakmai dilem- 
ma, hogy maga a kisgyereknevelői munka mennyire formalizált algoritmusokból áll, pontosabban, hogy mennyire merevek ezek a műveletek, ugyanúgy zajlanak-e a különböző intézményekben. Egy másik gyakorlat megismerése révén a hallgatót annak átgondolására kívánjuk sarkallni, hogy melyek szakmájának esszenciális, változtathatatlan részei, és melyek azok, melyeknek a helyi sajátosságokhoz, egyéni igényekhez mérten változtathatók, sőt, adaptálandók.

Végül, a kisgyermeknevelőként dolgozó hallgatóinknál óhatatlanul kialakulhat olyan helyzet, hogy egy korábbi mentorunk beiratkozik a képzésre, s ezáltal saját csoporttársának, szaktársának gyakorlatvezetőjévé válik, mely összeférhetetlen helyzet és kiszűrése, megelőzése odafigyelést kíván.

\section{Hallgatói alkalmasság megítélése}

A gyakorlati képzés utolsó és talán legkényesebb kérdése a hallgatók pályaalkalmasságáról szól. Amennyiben a gyakorlatvezetőben felmerül, hogy a hallgató gyakorlati teljesítménye nem kielégítő a szakmai gyakorlat elégséges értékeléséhez, akkor a gyakorlati képzés koordinátorával közösen döntenek az értékelésről. Amennyiben az elméleti órákon is tapasztaljuk a teljesítményproblémát (pl. nagyon alacsony szintű csoportos feladatban való felelősségvállalás esetén), akkor előfordul, hogy a gyakorlatvezetőknél célzottan és proaktív módon rákérdezünk a hallgató gyakorlati teljesítményére. Igyekszünk óvatosnak lenni a szakmai gyakorlat elégtelenre való osztályzásában, mivel két elégtelen osztályzat a szakról való elbocsájtást vonja maga után. Általában könnyebb dönteni azokban az esetekben, amikor a hallgató nem teljesíti a követelményeket, határidőkkel csúszik, nem kommunikál az oktatásszervezővel vagy az oktatóval, gyakorlatvezetővel. A társas viszonyulás nehézségei esetén az optimális az lenne, ha az oktató meg tudná figyelni a csoportban a hallgató gyermekekkel való bánásmódját, illetve a kollégákkal való kommunikációját és nem kizárólag a gyakorlatvezető elmondására kellene támaszkodnia. Természetesen ilyenkor mind a hallgató, mind a gyakorlatvezető álláspontját meg szoktuk hallgatni a döntés előtt.

\section{Összegzés}

Az eredményes, jól működő gyakorlati képzési rendszer kialakítása adott feltételek és keretek között sok szempont érzékeny összehangolását igényli. Megfogalmazódnak minőségi kívánalmak az egyetemi képzés és a szakma oldaláról, miközben felelősségteljesen kell gondolkodnunk a bölcsődei ellátást igénybe vevő gyerekek igényeiről is. A reflektív gondolkodás nem csak célként, hanem állandó gyakorlatként is jelen van a képzési program ciklikus fejlesztésében.Az előzőekben áttekintett problémakörök jól érzékeltetik, hogy milyen fontos a párbeszéd és az együttműködés az egyetemi szereplők és a szakma kompetens képviselői között.

\section{Felhasznált irodalom}

Bata Teodóra, Koppány Ivett, Pósfainé Sebestyén Bianka, Szurominé Balogh Mónika és Tolnayné Falusi Mária (2016): Kiegészitő útmutató az Oktatási Hivatal által kidolgozott Útmutató a pedagógusok minösitési rendszeréhez címü felhasználói dokumentáció értelmezéséhez. A bölcsödében, mini bölcsödében pedagógus munkakörben foglalkoztatottak részére. Oktatási Hivatal, Budapest

URL: https://www.oktatas.hu/pub_bin/dload/ pem/bolcsode.pdf

Bertoye, P. \& Dumorand, C. (1957): Troubles de croissance du nourrisson par choc affectif (Growth disorders in the nursing child caused by affective shock). Revue d'hygiene et de medecine sociale, 5. 2. sz., 187-190.

Buettner, C., Lang, S. \& Jeon, L. (2018): Transforming a big system: Investments in research based models and resources. In: EECERA, 28th EECERA Annual Conference. 'Early Childhood Education, Families and Communities' Abstract book. Budapest, 155-156.

Csatári Irén (1985): A védőnőhallgatók csecsemőotthoni gyakorlatának tapasztalatai. Egészségügyi Munka, 32. 2. sz., 44-46. 
A csecsemő- és kisgyermeknevelő szak gyakorlati képzése - kihívások

Davidson, F. \& Maguin, P. (1976): Les creches. Rózsáné Cigány Enikő és Aggné Pirka Veronika ESF, Paris.

Falk Judit (1985): A bölcsődei és csecsemőotthoni gyakorlat az egészségügyi szakdolgozók közép- és felsőfokú képzésében. Egészségügyi Munka, 32. 9. sz., 272-279.

Farkas Márta (1966): A csecsemőgondozó-nővérképzés kérdéséhez (Hozzászólás Pikler Emmi „A hospitalizáció elleni küzdelem egyik részletkérdéséről” című cikkéhez). Orvosi Hetilap, 107. 29. sz., 1386-1387.

Nyitrai Ágnes (2016): A gondozónőképzéstől a kisgyermeknevelő-képzésig. Mozaikok a bölcsődei szakemberképzés történetének 1970 és 2009 közötti időszakáról. In: Jávorka Gabriella Bölcsődevezetők kézikönyve (old.: aug A6). Raabe Klett, Budapest.

Péterné Pikler Emmi (1966a): A hospitalizáció elleni küzdelem egyik részletkérdéséről. Orvosi Hetilap, 107. 4. sz., 166-168.

Péterné Pikler Emmi (1966b): A csecsemőgondozó-nővérképzés kérdéséhez. (Válasz Farkas Márta hozzászólására). Orvosi Hetilap, 107. 29. sz., 1387.

Rheingold, H. L. (1956): The Modification of Social Responsiveness in Institutional Babies. Monographs of the Society for Research in Child Development, 21. 2. sz., 1-48. https://doi.org/10.2307/1165614 (2014): Módszertani segédanyag a csecsemöés kisgyermeknevelö BA-szak gyakorlati képzéséhez. ELTE Tanító- és Óvóképző Kar, Budapest.

URL: http://tamop2014.tok.elte.hu/dok/ szakmai_anyagok/gyakorlati_kepzes_ megujitasahoz/csecsemo/Rozsane_Czigany_ Aggne_2014_Modszertani_segedanyag_ csecsemo_BA_gyakorlati_kepzesehez.pdf.

Stróbl Mária (1984): A bölcsőde mint gyakorló terület. Egészségügyi Munka, 31. 7. sz., 205-210.

Stróbl Mária (1985): Még egyszer a bölcsődei gyakorlatról. Egészségügyi Munka, 32. 9. sz., 280-284.

Szél, É. (1985): A bölcsőde és a csecsemőotthon mint gyakorló terület. (Hozzászólás az oktatás szemszögéből). Egészségügyi Munka, 32. 3. sz., 73-77.

Szivák Judit (2014): Reflektív elméletek, reflektív gyakorlatok. ELTE-Eötvös, Budapest.

Tietze, K.-O. (2016): Kollegiale Beratung. Problemlösungen gemeinsam entwickeln. Rowohlt Taschenbuch Verlag, Reinbeck bei Hamburg.

Vokony Éva (2002): Kis magyar bölcsődetörténet. Kapocs, 1. 2. sz., 50-54.

\section{Practical training of the infant and early childhood education - major challenges}

There are several aspects to consider when designing the practical training for an Infant and Early Childhood Education degree. Those involved in the nursery placement - such as students, academics, nursery managers, mentors, nursery staff, children and their families, and members of related professions - can take opposing views of what is important. In this article, we review the aspects that we usually take into consideration when organizing the practical training at the Eötvös Loránd University's Faculty of Primary and Pre-School Education. We have uncovered these dilemmas by asking for continuous feedback from our students and mentors.

Keywords: Infant and Early Childhood Education degree, practical training, course planning 